\title{
Radical changes in the Wadden Sea fauna and flora over the last 2,000 years
}

Received: 27 May 2004/ Revised: 21 September 2004/ Accepted: 23 September 2004/Published online: 2 February 2005

(C) Springer-Verlag and AWI 2005

\begin{abstract}
Humans have interacted with the Wadden Sea since its origin 7,500 years ago. However, exploitation, habitat alteration and pollution have strongly increased since the Middle Ages, affecting abundance and distribution of many marine mammals, birds, fish, invertebrates and plants. Large whales and some large birds disappeared more than 500 years ago. Most small whales, seals, birds, large fish and oysters were severely reduced by the late 19th and early 20th centuries, leading to the collapse of several traditional fisheries. In the 20th century, conservation efforts have enabled some breeding birds and seals to recover. But other species declined further due to continuing exploitation, habitat destruction, pollution and eutrophication. Moreover, complex three-dimensional habitats such as oyster banks, Sabellaria reefs and subtidal eelgrass beds have been lost completely. In contrast, several opportunistic species such as gulls, polychaetes, green algae and exotic invaders increased during the 20th century. Taken together, multiple human impacts have caused dramatic losses of large predators and habitat-building species in the Wadden Sea over the last 500 years. Although still of high natural value and global importance, the Wadden Sea is a fundamentally changed ecosystem. On the other hand, reduced hunting pressure, increased habitat protection and reduced river pollution have enabled the recent recovery of several species and an increase in
\end{abstract}

Communicated by H.K. Lotze and K. Reise

H. K. Lotze

Alfred Wegener Institute for Polar and Marine Research, Wadden Sea Station Sylt, 25992 List, Germany

H. K. Lotze

Leibniz-Institute for Marine Science,

Düsternbrooker Weg 20, 24105 Kiel, Germany

Present address: H. K. Lotze $(\square)$

Department of Biology, Dalhousie University,

Halifax, Nova Scotia, B3H 4J1, Canada

E-mail: hlotze@dal.ca

Tel: + 1-902-494-2478

Fax: + 1-902-494-3736 environmental quality. These successes, together with a historical vision of what was once possible, should guide current and future conservation, restoration and management efforts towards a more sustainable interaction between man and the sea.

Keywords Conservation - Environmental history Extinction - Multiple human impacts · Recovery

\section{Introduction}

About 7,500 years ago, retreating glaciers and the subsequent sea level rise created the Wadden Sea, a unique coastal ecosystem in the southeastern North Sea (Flemming 2002). At present, the Wadden Sea is considered the largest intertidal system and one of the most important coastal wetlands worldwide (Wolff 1983; Meltofte et al. 1994; Reise 2005). Protection efforts started in the early 20th century and were intensified in the 1980s with the Joint Declaration on the Protection of the Wadden Sea between Denmark, Germany and the Netherlands and the establishment of national nature reserves (de Jong et al. 1999). Today, the Wadden Sea is under discussion to be designated as a UNESCO Natural World Heritage site.

Despite its great natural value, the Wadden Sea is a fundamentally altered ecosystem due to a long history of human intervention (de Jonge et al. 1993; see also Lotze et al. 2005). At least over the past 2,000 years, humans have been a major driver of change in the Wadden Sea through resource exploitation, habitat alteration and pollution (Wolff 1992a, 1992b, 2000a,2000b). However, humans have fished, hunted birds and mammals, and harvested shellfish and plants since prehistoric times (Knottnerus 2001). Since about 1,000 years ago, the reclamation of coastal marshes has largely changed the Wadden Sea land- and seascape, causing an unprecedented loss and alteration of habitat for many species (Wolff 1992b; Reise 2005). Furthermore, during the last 
two centuries, large-scale overfishing, eutrophication and chemical pollution have had strong cumulative effects on marine species (Wolff 1992a; de Jonge et al. 1993).

In this paper, an overview is provided on the historical patterns of change in the marine fauna and flora of the Wadden Sea. My main objective was to outline the major changes that occurred in different species groups, as illustrated by examples, rather than to provide an extensive review of changes in every single species. For this purpose, all available archaeological, historical and recent scientific literature and data for marine mammals, birds, fish, macrobenthic invertebrates and marine plants were reviewed. The terrestrial vegetation (e.g. salt marshes, dunes) as well as microscopic plants and animals are not considered in this overview. Causes and consequences of ecological changes for food-web and ecosystem structure and functioning are discussed in the conclusions.

\section{Study region}

The region considered in this review is the modern Trilateral Wadden Sea Cooperation area from Den Helder, the Netherlands, to Blåvandshuk, Denmark, including the estuaries and coastal waters inside and outside the barrier islands (de Jong et al. 1999). For archaeological evidence and species with greater distribution ranges I also considered the larger southern North Sea region and the coast from Calais, France, to the Jammerbugt, Denmark, which belonged to the Wadden Sea system at the time of its maximum extent during the Holocene transgression period (Flemming 2002).

\section{Marine mammals}

In the 20th century, only four marine mammal species belonged to the regular fauna of the Wadden Sea: the harbour seal (Phoca vitulina), grey seal (Halichoerus grypus), harbour porpoise (Phocoena phocoena) and bottlenose dolphin (Tursiops truncatus) (von Nordheim et al. 1996). Another three species of pinnipeds and about 20 species of cetaceans are only seen occasionally in coastal waters or when stranded (Reijnders and Wolff 1981; Benke and Siebert 1994; Schwarz and Heidemann 1994). Archaeological and historical data, however, indicate that large cetaceans were also common in the North Sea during the Middle Ages and earlier (De Smet 1981; Bryant 1995; Wolff 2000a,2000b).

\section{Extirpation of large whales}

Gray whales (Eschrichtius gibbosus) and northern right whales (Eubalaena glacialis) are coastal species that once occurred in the southeastern North Sea and probably also in the Wadden Sea (De Smet 1981; Wolff 2000b).
Other large cetaceans were probably never more than stragglers (Reijnders and Wolff 1981), but were used by coastal people when stranded. Archaeological findings from around the North Sea indicate the presence of gray whales from 8,330 to 340 years ago, but this species went extinct in the entire North Atlantic in the 17th or 18th century (Bryant 1995; Wolff 2000b). De Smet (1981) suggested that the Wadden Sea might have provided an important calving ground for the gray whale. In turn, as a benthos feeder leaving feeding pits up to $4 \mathrm{~m}$ long at the bottom (Johnson and Nelson 1984), the gray whale would have had an important role in the ecosystem in former times. The right whale was also abundant until the late Middle Ages (De Smet 1981; Wolff 2000b), but is extremely rare in European waters today (Perry et al. 1999). Because they were coastal, slow swimmers and floated when dead, the gray and right whale were the main targets for early whalers (De Smet 1981; Bryant 1995). From at least the ninth century onwards, and throughout the Middle Ages, regular hunting of whales occurred in the southern North Sea (De Smet 1981). Because whales became scarce, commercial whaling operations moved further north and west to Spitsbergen, Greenland, and Newfoundland in the 16th century (Bryant 1995). Both the gray and right whale disappeared during a period of active coastal whaling, which either caused or contributed to their decline (Bryant 1995).

\section{Depletion of small whales}

The harbour porpoise and bottlenose dolphin were the most common small cetaceans in the southern North Sea and regularly occurred in the Wadden Sea until the early 20th century (Kremer 1990; Benke and Siebert 1994; Wolff 2000b). In the Dutch Wadden Sea, the bottlenose dolphin disappeared after reclamation of the Zuiderzee in 1937 and the disappearance of Zuiderzee herring, its common spring prey (Wolff 2000b). It continued to occur offshore, but strongly decreased after 1965, a trend observed for the entire southern North Sea (Kremer 1990). Today, the species is considered a rare visitor in the Wadden Sea (von Nordheim et al. 1996). The harbour porpoise used to be very common in coastal waters from the Netherlands to Denmark in the 19th and early 20th centuries. A population decline was observed in the 1940s to 1950s, and again in the 1960s. Today, the species is rare in inshore waters (Kremer 1990; von Nordheim et al. 1996; Wolff 2000b). However, since the 1980s numbers of stranded porpoises in the North Frisian and Dutch Wadden Sea have increased (Kremer 1990; Marine Mammal Database, available online at http://home.planet.nl/ camphuys/Bruinvis.html). This might indicate a slight recovery of the population, but may also be linked to increased fishing mortality.

Porpoises and dolphins were hunted for oil and flesh in the Middle Ages and until the 20th century (De Smet 1981; Knottnerus 2001). Archaeological remains from 
the second century to the late Middle Ages contain porpoise bones (Kremer 1990; Reichstein 1994), and historical sources indicate that porpoise meat was common in Medieval markets (De Smet 1981). In the 20th and 21st centuries, pollution with heavy metals and PCBs, disturbance and high bycatch rates in the fisheries have been major causes for observed declines (Kremer 1990; Benke and Siebert 1994; von Nordheim et al. 1996).

Depletion and recovery of seals

The grey seal was the most common seal found in archaeological remains in the Wadden Sea dating up to the Middle Ages (Wolff 2000b; Prummel and Heinrich 2005). Since about 1,500 A.D., reports have been scarce, and the grey seal was extremely rare until the mid-20th century. Successful conservation in Great Britain, however, led to a population increase in the North Sea and the re-colonization of the Wadden Sea (Wolff 2000b). In 1967, a small permanent colony established itself near Amrum, and in 1980 a second colony was established near Terschelling (von Nordheim et al. 1996), which has increased to more than 350 animals over the past decade (Fig. 1).

The harbour seal has been hunted since at least the eighth century and in the Middle Ages, as indicated by archaeological remains (Heinrich 1994; Prummel and Heinrich 2005), and hunting continued into the 20th century (Reijnders 1992). Reduced hunting pressure and increased habitat protection in the second half of the 20 th century, however, resulted in a recovery of the population from a low of 3,000 animals in 1974 to more than 15,000 in 2003 (Fig. 1). Two disease outbreaks that reduced the population by $60 \%$ in 1988 and by $40 \%$ in 2002 slowed down, but did not prevent, recovery (Reineking 2002). However, today's harbour seal population is still far from its estimated potential abundance of 37,000 animals in 1900 (Fig. 1; Reijnders 1992).

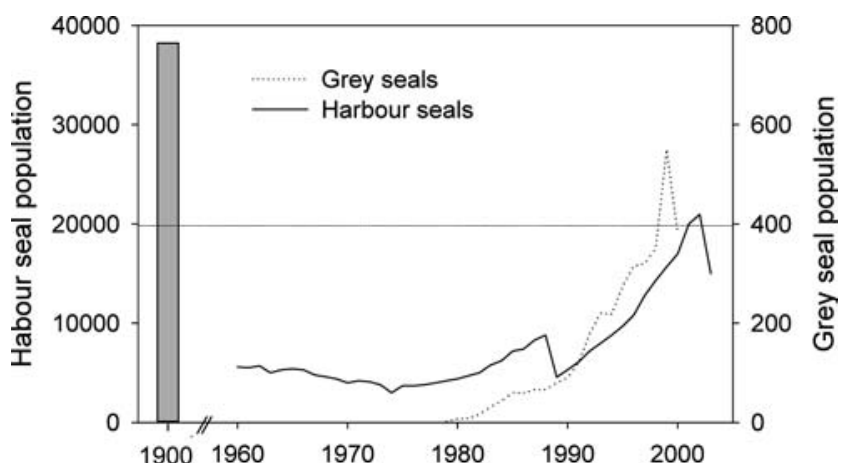

Fig. 1 Population trends of harbour seals (solid line) and grey seals (dotted line) in the Wadden Sea since 1960 as estimated from aerial counts (data adapted from Reijnders 1992; de Jong et al. 1999; Reineking 2002; TSEG 2002). The gray bar on the left indicates the potential abundance estimate for harbour seals in 1900 (after Reijnders 1992)

\section{Coastal birds}

The Wadden Sea is of international importance for at least 54 species or subspecies of migratory waterbirds and 15 species or subspecies of resident or breeding birds (von Nordheim et al. 1996). About 350,000-400,000 pairs of breeding birds, as well as 10-12 million migratory waterbirds, use the Trilateral Wadden Sea as a feeding, staging, roosting and moulting area every year (von Nordheim et al. 1996).

Hunting, habitat loss, and bird declines

Hunting for food and feathers as well as egg and down collection has occurred along the coast since prehistoric times (Knottnerus 2001), and numerous coastal species are found in archaeological remains (Prummel and Heinrich 2005). In the Middle Ages, many species became of commercial importance, and colonially breeding birds in particular suffered from high exploitation pressure. Thus, in the 16th century, the first regulations were imposed to manage hunting of cranes (Grus grus), swans (Cygnus spp.), herons (Ardea spp.), egrets (Egretta spp.), cormorants (Phalacrocorax carbo), spoonbills (Platalea leucorodia) and shelducks (Tadorna tadorna) (van Eerden 1997). Some species, such as swans, were known to become exterminated rather easily (van Eerden 1997). In the 15th century, the Dutch invented duck decoys to lure swarms of wild ducks (Knottnerus 2001). Historical catch data from duck decoys on Sylt, Amrum and Föhr show extremely high numbers being caught up to 1930, suggesting that teal (Anas crecca) and pintail (A. acuta), at least, must have occurred in much higher numbers than they do today (Rösner 1994). High exploitation pressure since the Middle Ages caused the decline and disappearance of many bird species until the first protection efforts were introduced in the early 20th century (e.g. Løppenthin 1967; van Eerden 1997).

Habitat alteration and loss was another major factor affecting breeding and migratory birds. Until about 2,500 years ago, habitat change was caused by natural forces, particularly sea-level rise and fluctuations (Løppenthin 1967; van Eerden 1997). Then, humans started to open up forested areas and introduce agriculture and intensive cattle grazing. In the eighth century, peat exploitation began, and since the 12th or 13th century dikes and dams have been built to prevent flooding (van Eerden 1997). Over time, a diverse, multiple-habitat environment was transformed into a manmade agriculture-based landscape (van Eerden 1997). In the Netherlands, the natural landscape shrank from $100 \%$ in 850 A.D. to $50 \%$ in 1350 A.D., and to $7 \%$ in 1993 due to cultivation. In particular, transitional wetland habitats such as peatlands, bogs, salt marshes and mud flats were severely reduced as part of the landscape from $33 \%$ in the Middle Ages to $2 \%$ today (van Eerden 1997; 
see also Lotze et al. 2005). Based on paleographic and historical habitat analyses for the Netherlands, van Eerden (1997) suggested that great numbers of waterbirds have occurred over the last 2,000 years. For several species, habitat availability was greatest during the Middle Ages, when wetland areas reached their largest extent. Since the Middle Ages, however, human-induced habitat transformation has caused strong declines in benthivorous $(36 \%$ decrease), piscivorous $(45 \%)$ and planktivorous $(55 \%)$ birds. Among herbivorous birds, species which depend on natural food from salt marshes and eelgrass beds, such as brent (Branta bernicla) and teal, have declined two- to threefold since the Middle Ages. In contrast, those which adapted to new food sources available on agricultural fields such as graylag (Anser anser) and white-fronted goose (Anser albifrons) strongly increased, especially during winter (van Eerden 1997).

Early extinctions of large birds

Natural historians such as Plinii Secundi (1513) and Olaus Magnus (1555) had already mentioned the extinction of several birds in southern and northern Europe in the Middle Ages and earlier. Archaeological evidence from the Netherlands suggests the former occurrence of the white-tailed eagle (Haliaeetus albicilla) from 2,000 B.C. to 200 A.D., the Dalmatian pelican (Pelecanus crispus) from 2,400 B.C. to 200 A.D., and the greater flamingo (Phoenicopterus ruber) before 2,000 B.C. (Wolff 2000b). The Dalmatian pelican also occurred in Denmark from 4,000 to 2,000 B.C. (Løppenthin 1967), and the white-tailed eagle was found in German archeological sites dating from the 7th to the 13th century (Reichstein 1994; Walhorn and Heinrich 1999). Swennen (1991) suggested that the common eider (Somateria mollissima) used to breed in large parts of Northern Europe but disappeared at the end of the Middle Ages due to human persecution. Also, the great white egret (Egretta alba) was extirpated in the 14th century in the Netherlands (van Eerden 1997). Some of these species reestablished breeding populations in the Wadden Sea during the 20th century, e.g. white-tailed eagle, great white egret and common eider, while the former occurrence of other large and charismatic species is lost from living memory.

\section{Strong declines towards 1900}

Since the Middle Ages, high exploitation pressure and habitat loss reduced populations of at least 24 species of waterfowl (13), seabirds (5) and shorebirds (6) to very low numbers in the late 19 th and early 20 th centuries (Løppenthin 1967; Behm-Berkelmann and Heckenroth 1991; Meltofte et al. 1994; van Eerden 1997). For example, in the 19th century, numbers and distribution of spoonbills, cormorants, gulls (e.g. Larus canus, Larus fuscus) and herons (e.g. Ardea cinerea, Ardea purpurea) in the Netherlands were greatly diminished, and the squacco heron (Ardeola ralloides) became extinct c.1860 (van Eerden 1997; Wolff 2000b). In Denmark, breeding populations of the common crane disappeared in the early 19 th century, cormorants after 1876 , and the mute swan (Cygnus olor), common eider and other waterfowl populations strongly decreased in the late 19th and early 20th centuries (Løppenthin 1967). Similarly, shorebirds such as turnstone (Arenaria interpres), snipes (Gallinago gallinago, Gallinago media), golden plover (Pluvialis apricaria), ruff (Philomachus pugnax) and avocet (Recurvirostrata avosetta), and seabirds such as sandwich and Caspian tern (Sterna sandvicensis, Sterna caspia) strongly decreased or disappeared during the 19th and early 20th centuries (Løppenthin 1967).

\section{Recovery in the 20th century}

In the 20th century, protection of birds began through reduced hunting pressure and egg collection, and protection of habitat (Løppenthin 1967; van Eerden 1997). As a result, several birds recovered and re-colonized the Wadden Sea in the 20th century (Meltofte et al. 1994). For example, the great white egret started to breed again in the Netherlands in 1978 after a 600-year absence (van Eerden 1997), and the white-tailed eagle returned in the 1950s (Løppenthin 1967). In Niedersachsen, seven species of waterfowl including the common eider and shelduck (Fig. 2a), five seabirds including the herring (Larus argentatus) and black-headed gull (Larus ridibundus) (Fig. 2b), and six shorebirds including oystercatcher (Haematopus ostralegus) and avocet (Fig. 2c) have shown increasing breeding populations since the 1950s (Behm-Berkelmann and Heckenroth 1991). In addition to protection efforts, increased food supply supported geese feeding on grasslands and gulls feeding on garbage and fisheries offal (Meltofte et al. 1994).

\section{Further declines and extinctions in 20th century}

Despite increasing protection efforts, some species still suffered from continued hunting, habitat loss, disturbance and pollution, and declined or disappeared in the 20th century. Two seabirds (Caspian tern and roseate tern Sterna dougallii), which had bred in the German Wadden Sea until the early 20th century became extinct (von Nordheim et al. 1996; Wolff 2000b). Local extirpation of cormorants and spoonbills occurred in the Netherlands during the 20th century (van Eerden 1997). Moreover, the eelgrass disease in 1931-1932 (see Marine plants section below) caused a 75-90\% population crash of brents in Europe (Ganter 2000). After the crash, the birds eventually but slowly switched to alternative feeding habitats such as meadows and upland areas, a behavior that had never been observed before but enabled the population to recover (Ganter 2000). Since 
Fig. 2 Trends of breeding populations in Niedersachsen, Germany, since 1946 for selected waterfowls (a), seabirds (b), shorebirds (c), and two endangered marine birds (d). Numbers in brackets indicate multiplication factor for $y$-axis labels. Data adapted from Behm-Berkelmann and Heckenroth (1991)
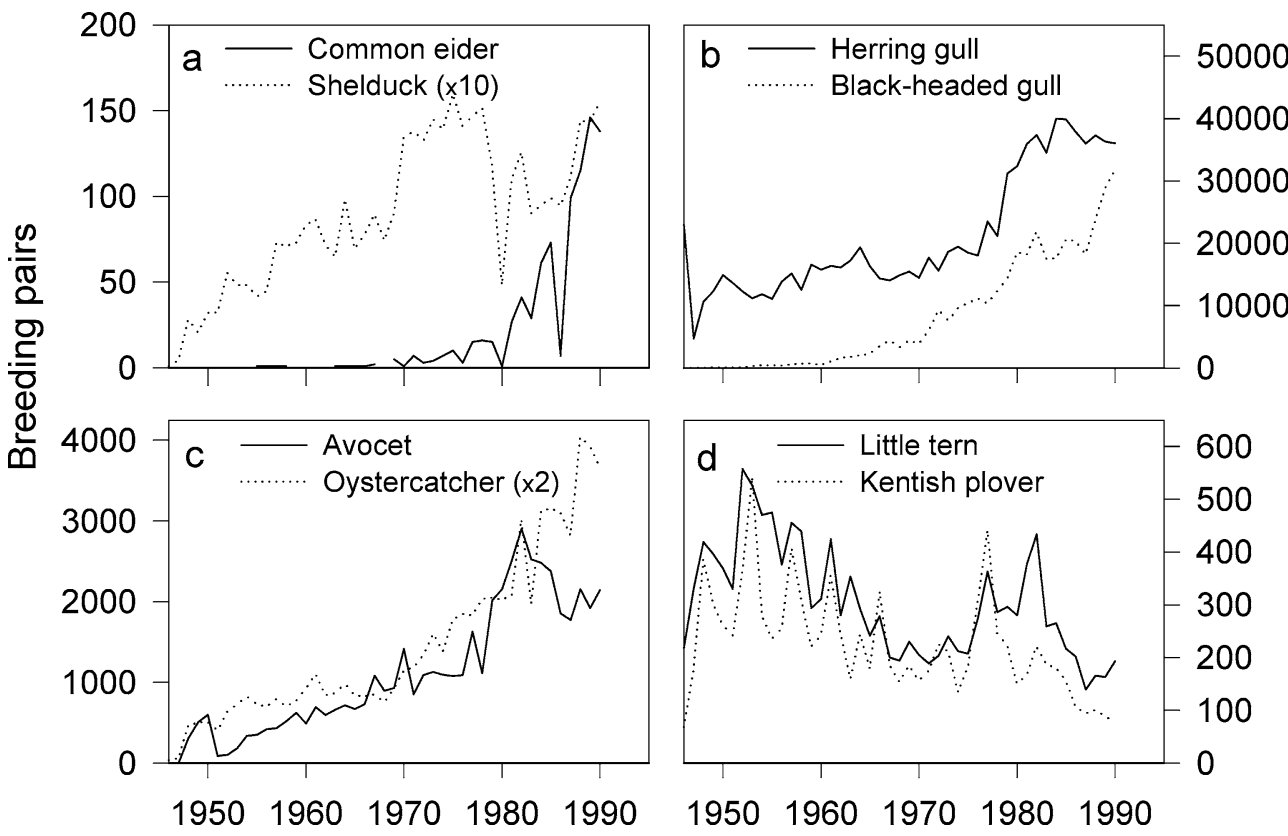

the 1950s, pollution with pesticides, deterioration of eelgrass beds, overexploitation of blue mussel and cockle stocks as well as disturbance of breeding sites on beaches have affected several birds, and declining population trends have been observed for three waterfowls (e.g. teal), three seabirds (e.g. little tern Sterna albifrons; Fig. 2d) and two shorebirds (e.g. Kentish plover Charadrius alexandrinus; Fig. 2d) (Behm-Berkelmann and Heckenroth 1991; Meltofte et al. 1994). Today, 16 marine bird species are listed as critical, endangered, vulnerable or susceptible (von Nordheim et al. 1996).

\section{Fish}

In the Wadden Sea, 162 fish and lamprey species are known, of which 90 are residents and 72 migrants (von Nordheim et al. 1996). Today, 19 species are listed on the Red List, two of which are probably extinct, and another 16 species are rare and probably threatened (von Nordheim et al. 1996). The Wadden Sea provides a variety of habitats that support diverse fish communities such as freshwater rivers, estuaries and brackish water lagoons, sheltered waters inside the barrier islands, tidal channels and open waters outside the barrier islands, and it is an important nursery and feeding area for many fish that are of commercial importance (Dankers et al. 1978; Lozan et al. 1994).

Strong decline in large groundfish

Fishing has occurred in the Wadden Sea since people settled near the coast. Even in prehistoric and Roman times, people had seaworthy boats and even the oldest marshland settlements (e.g. Vlaardingen, Netherlands,
3,500-2,500 в.C.) reveal traces of haddock (Melanogrammus aeglefinus) (Knottnerus 2001). Haddock and cod (Gadus morhua) were important food fish for people along the coast from the 1st to the 17th century A.D. (Enghoff 2000). Remarkably, large cod reaching sizes of 95-130 cm were found in several places. Historical sources indicate that the coastal fishery for haddock and cod has been of great importance since at least the 16th century near the east Frisian islands, the north Frisian coast, around the island of Helgoland, and in Denmark (Lozan 1990; Holm 2005). Old catch statistics indicate that the handline fishery near Helgoland yielded about 2 million haddock per year in the late 18th century, but the fishery declined and came to an end in the early 20th century (Fig. 3; Lozan 1990, 1994). The fishery for rays (Raja spp.) became important near the north Frisian islands in the 16th century (Lozan 1994). In the late 19th

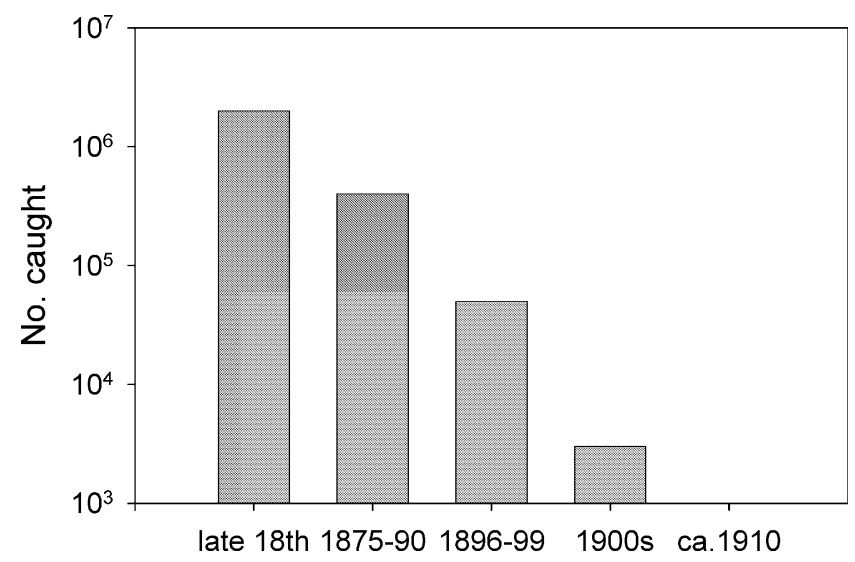

Fig. 3 Decline of haddock landings in the handline fishery near Helgoland, Germany, from the late 18th to early 20th century. Data adapted from Lozan $(1990,1994)$ 
century, the fishery for thornback ray (Raja clavata) and common skate (Raja batis) was intensified because of declining groundfish catches, but lasted only until the mid-20th century (Fig. 4), probably because of high exploitation pressure. Today, these large ray species, as well as other large groundfish, are very rare in the Wadden Sea (de Vooys et al. 1991; Lozan 1994; von Nordheim et al. 1996). In the 20th century, fisheries for large groundfish moved offshore into the North Sea, but ceased to exist in coastal waters. However, large groundfish are still threatened in coastal waters as bycatch in bottom fisheries, and strong declines of several species were observed during 1945-1980 (Philippart 1998).

Loss of diadromous fish around 1900

Many rivers discharging into the Wadden Sea, such as the Rhine, Ems, Weser, Elbe and Eider, were important for anadromous fish such as European sturgeon ( $\mathrm{Aci}$ penser sturio), Atlantic salmon (Salmo salar), sea trout (Salmo trutta), allis shad (Alosa alosa) and houting (Coregonus oxyrhynchus). These fish were very abundant in earlier centuries and served important fisheries. Archaeological evidence suggests that the sturgeon was the most important fish used by people of Feddersen Wierde near the River Weser, Germany, in Roman times, and the salmon and sea trout were important food fish near Ribe, Denmark, in the Middle Ages (Enghoff 2000; Prummel and Heinrich 2005). Even in the Middle Ages, declines of highly valued sturgeon and salmon were noticed in rivers throughout Europe as a result of habitat alteration, damming and high fishing pressure (Hoffmann 2005; Prummel and Heinrich 2005). As a

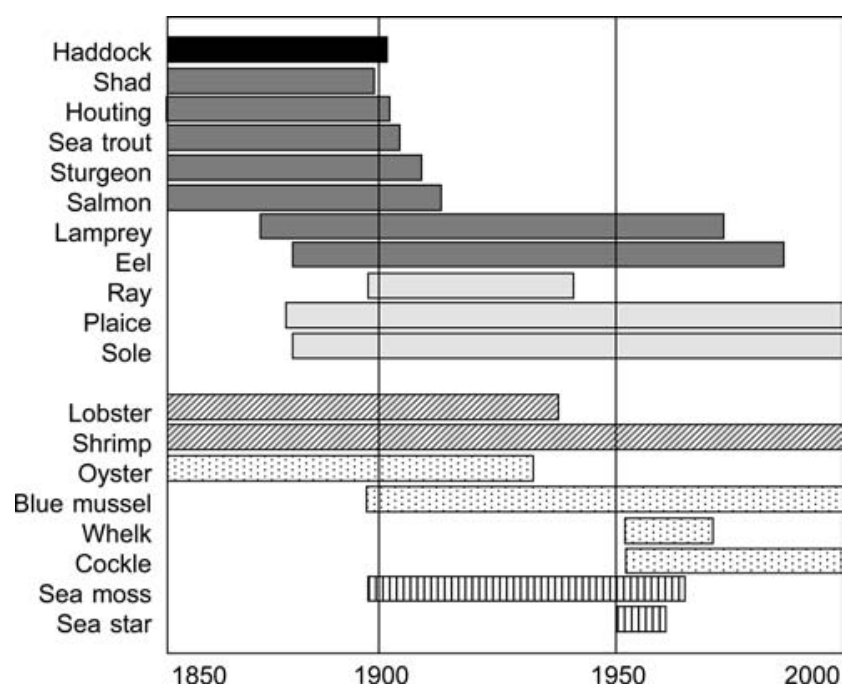

Fig. 4 History of the coastal fisheries for groundfish (black), diadromous fish (dark grey), flatfish (light grey), crustaceans (diagonally hatched), shellfish (dotted) and other invertebrates (hatched) in the German Wadden Sea. Data adapted from Lozan (1994) response, the fisheries moved from upriver and inland to the river mouths and estuaries (Hoffmann 2005). In the 19th century, big commercial fisheries developed in many cities along the coast (Lozan 1990; Debus 1996). From 1890 to 1910, strong declines in landings and average length of the sturgeon were observed in German and Dutch rivers and the fishery ceased (Fig. 5; Mohr 1952). Similar trends were described for other diadromous fish (Fig. 4; Lozan 1990, 1994). Since the 1920s to 1930s, natural populations of sturgeon, salmon, sea trout, allis shad and houting have been extinct or critically endangered (von Nordheim et al. 1996). The major causes for declines in diadromous fish are overexploitation, habitat loss through damming of rivers or destruction of spawning habitat, and degradation of river water quality through pollution and oxygen deficiency (Lozan et al. 1994; Debus 1996).

\section{Decline in inshore and estuarine fish}

Various inshore fish such as flatfish, eel (Anguilla anguilla), herring (Clupea harengus), anchovy (Engraulis encrasicholus) and smelt (Osmerus eperlanus) were important to people around the coast between the 1st and 16th centuries (Enghoff 2000; Knottnerus 2001). Despite their long tradition, these inshore fisheries were intensified only in the late 19 th and early 20 th century because of the decline in traditionally valued groundfish and diadromous fish (Fig. 4; Lozan 1990, 1994). For example, annual landings of flounder (Platichthys flesus) in the lower Elbe river reached 280 tons year ${ }^{-1}$ in 1887 1918 , but dropped to 8.3 tons year ${ }^{-1}$ (3\% of former levels) in 1962-1973 (Lozan 1990). The Danish fishery for dab (Limanda limanda) peaked in the early 20th century but came to an end in the 1950s (Holm 2005). Since the 1970s, landings of flounder and also eel continued to decline. Major reasons for long-term declines are high fishing pressure as well as habitat degradation and pollution in estuarine and river habitats (Lozan 1990, 1994; Holm 2005). The fishery for other flatfish,

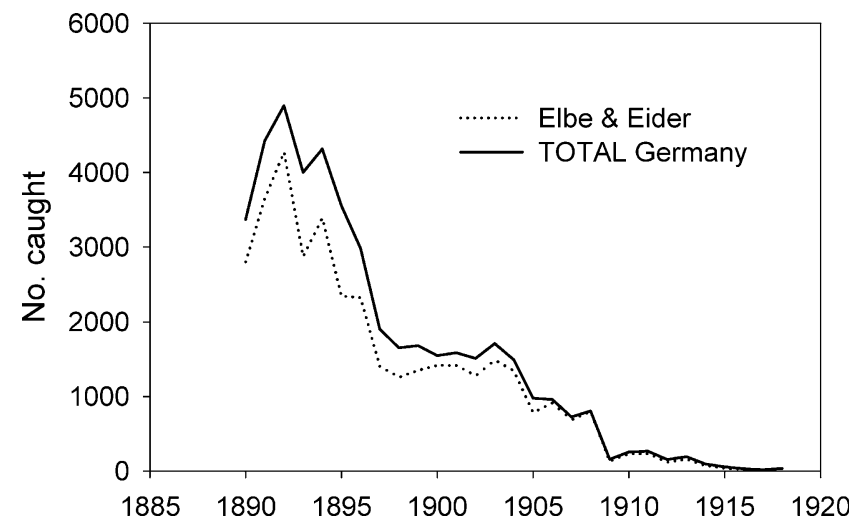

Fig. 5 Decline of sturgeon landings in the rivers Elbe and Eider, and the entire German Wadden Sea from 1890 to 1918. Data adapted from Mohr (1952) as cited in Lozan (1990) 
especially for plaice (Pleuronectes platessa) and sole (Solea solea) was commercialized in the late 19th century, intensified in the early 20th century, and continued until today (Fig. 4; Lozan 1994). Data for the entire North Sea fishery indicate, however, that plaice and sole landings and biomass declined during the 1990s (Lozan and Zimmermann 2003). Between 1920 and 1970, herring and sprat (Sprattus sprattus) were intensely fished in estuaries and inshore waters, reaching a peak in the 1930s (Lozan 1994). Since then, landings have declined and the entire North Sea herring stock has become so reduced that the herring fishery was closed in 1978-1983. The stocks briefly recovered but reached another low in the mid-1990s (Zimmermann and Hammer 2003).

Long-term abundance trends for other inshore species were extracted from bycatch data in the German shrimp fishery between 1954 and 1988 (Tiews 1983, 1990). The data indicate strong declines for the eel, gray gurnard (Eutrigla gurnadus), common goby (Pomatoschistus minutus), sea snail (Liparis liparis), solonette (Buglossidium luteum) and sole. On the other hand, abundance of the smelt has not changed much since the 1950s, but the smelt fishery declined during recent decades because of decreasing demand and high pollution levels of the fish, especially in the Elbe estuary (Lozan 1990, 1994). The loss of eelgrass beds as important fish habitat caused the decline of pipefishes (Syngnathus acus, S. typhle) and stickleback (Spinachia spinachia) which today are vulnerable and endangered, respectively (de Jonge et al. 1993; von Nordheim et al. 1996). Moreover, the closure of the Zuiderzee in 1932 caused the virtual extinction of a morphologically distinct Zuiderzee herring race (de Jonge et al. 1993; Wolff 2000b).

High pressure on offshore fish stocks

Offshore marine fishing probably started in the Middle Ages, when formerly preferred freshwater and diadromous fisheries declined in Europe, and the fisheries expanded to new markets and fishing regions (Hoffmann 2005). In the 12th to the 14th century, an important commercial herring fishery occurred around Helgoland: the herring were salted and marketed far inland (Knottnerus 2001; Hoffmann 2005). The fishery for groundfish expanded to the Doggerbank in the late Middle Ages (Knottnerus 2001). Both the pelagic and groundfishery continued over the centuries, but were strongly intensified in the 20th century. In the North Sea, landings of important commercial fish increased from less than 1 million tons year ${ }^{-1}$ in 1900 to a peak of greater than 3.5 million tons year ${ }^{-1}$ in 1970 (Froese and Pauly 2003). Since then, landings and trophic levels of species caught continuously declined. Today, $60 \%$ of fish stocks have collapsed or are overfished (Froese and Pauly 2003). Jennings and Blanchard (2004) estimated that today's biomass of large fish $(>4 \mathrm{~kg})$ in the North Sea is more than $97 \%$ lower than what it would have been without fisheries. As a general trend for the North Atlantic, Christensen et al. (2003) estimated that predatory fish biomass has declined by a factor of nine since 1900.

\section{Macrobenthic invertebrates}

The zoobenthos of the Wadden Sea contains about 1,250 species, of which 400 belong to the macrobenthos (>1 mm) (Dankers et al. 1981; von Nordheim et al. 1996). The tidal flats, in particular, are characterized by very high benthic biomass and productivity, which is dominated by molluses and polychaetes (Dankers et al. 1981).

\section{Decline in invertebrate fisheries}

Throughout history, people living near the Wadden Sea supplemented their diets with large amounts of shellfish and crustaceans (Enghoff 2000; Knottnerus 2001). A commercial fishery first developed for European oysters (Ostrea edulis) around 1,000 A.D. The east Frisian oyster beds were first mentioned in 1642 and landings peaked in the late 18th century, followed by a strong decline and collapse in the 19th century (Fig. 6a; Neudecker 1990). The north Frisian oyster beds were first mentioned in 1241 and privatized to the Danish King in 1587 (Hagmeier and Kändler 1927; Neudecker 1990). A loss of oyster beds was noticed in the early 1800 s, and landings strongly declined in the late $1870 \mathrm{~s}$ (Fig. 6b). Regulations and fishery closures were imposed around 1900, but the decline could not be halted and the fishery collapsed between 1925 and 1950 (Figs. 4 and 6b; Reise 1998). To replenish overexploited native stocks, the Pacific oyster (Crassostrea gigas) was introduced in the 1960s and 1970s (Drinkwaard 1999). Landings from cultured stocks in the Netherlands have strongly increased during recent decades (Fig. 6c). Subsequently, the Pacific oyster spread and established wild populations in several parts of the Wadden Sea in the 1990s (de Jong et al. 1999). A commercial fishery for the lobster (Homarus gammarus) developed mainly around Helgoland in the 17th century and lasted until the early 20th century (Fig. 4). In the 19th and 20th centuries, commercial fisheries also developed for the shrimp (Crangon crangon), blue mussel (Mytilus edulis), cockle (Cerastoderma edule), soft-shelled clam (Mya arenaria) and common whelk (Buccinum undatum), but the sea moss (Sertularia cupressina, a hydroid) and sea stars (Asterias rubens) were also targeted at times (Fig. 4; Lozan 1994). During the 20th century, several invertebrate fisheries collapsed because of overexploitation (e.g. oyster, lobster) or ceased because of declining markets (e.g. clam, sea moss, sea star) (Fig. 4). Today, only fisheries for the blue mussels and shrimp are still of commercial importance (Dahl et al. 1994; Lozan 1994). 
Loss of habitat-building species

The dominant feature of the Wadden Sea are its softsediment tidal flats. A century ago, however, complex, three-dimensional habitats were provided by oyster banks, polychaete reefs of Sabellaria spinulosa ('sand coral'), sea moss stands, mussel beds and seagrass meadows (see Marine plants section). These diversified the Wadden Sea landscape and provided diverse habitats for a variety of species which depended on hard substratum, protection or food supply. For example, oyster banks once supported rich communities of sponges, sea
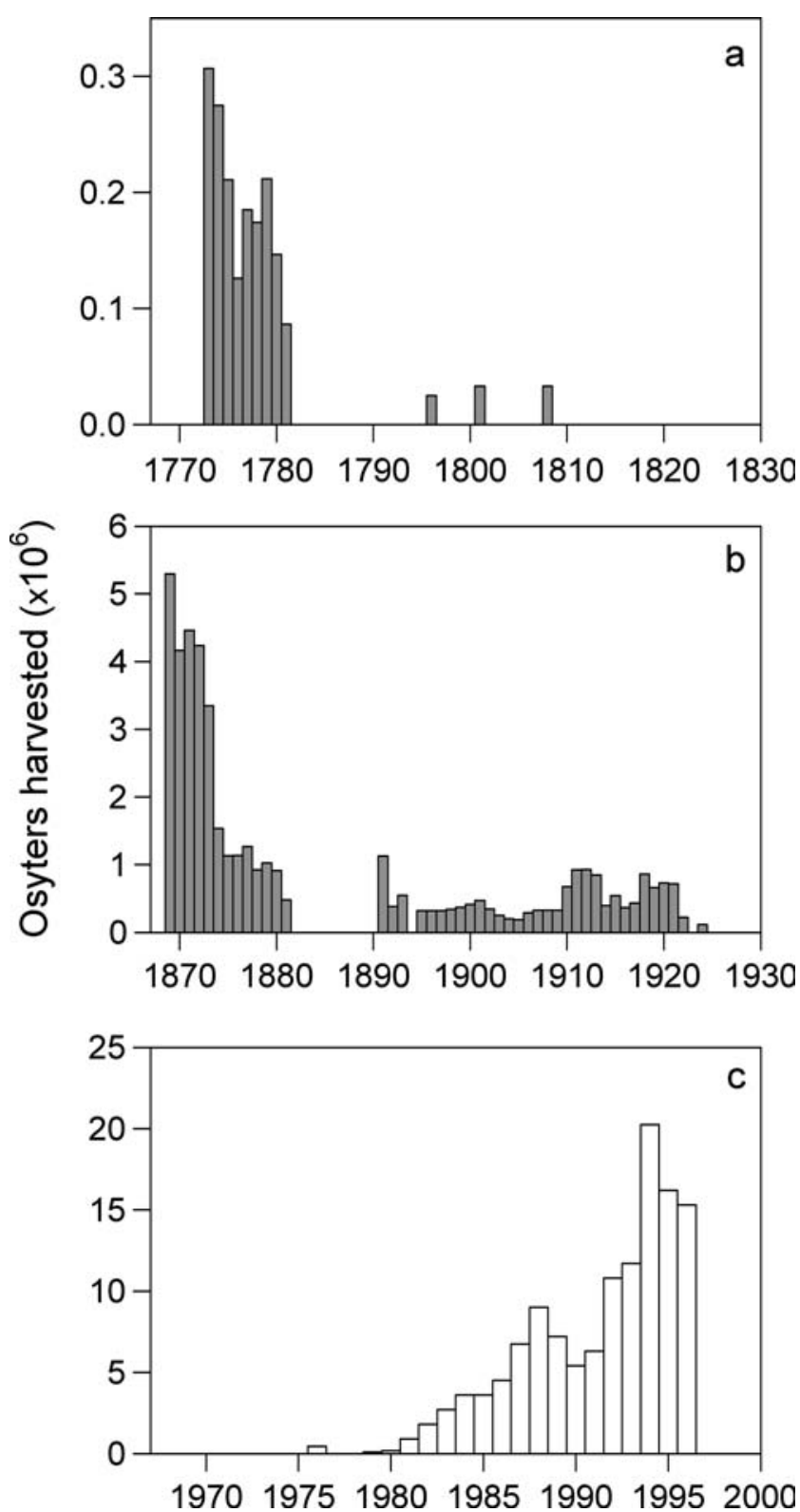

Fig. 6 Annual landings of European oysters (in millions) (a) in the east Frisian Wadden Sea 1770-1830; and (b) in the north Frisian Wadden Sea 1868-1930; and (c) landings of cultured Pacific oysters in the Netherlands 1970-2000. Data adapted from Hagmeier and Kaendler (1927), Neudecker (1990) and Drinkwaard (1999) anemones, hydroids, worms, sea urchins and other species (Reise 1990). Most habitat-building species were heavily exploited or destroyed directly or indirectly by fisheries during the 20th century. With the loss of their hosts, associated species disappeared as well (Reise et al. 1989). For example, Sabellaria reefs were once characteristic of tidal channels of the east and north Frisian Wadden Sea, with rich associated communities, but only small relicts remain today (Michaelis and Reise 1994). Plentiful sea moss stands used to be common on oyster banks and mussel shells, but were dredged and marketed for decoration purposes until the 1950s (Fig. 4; Reise et al. 1989; Michaelis and Reise 1994). The recovery of sea moss colonies was impaired by continuous, largescale bottom fisheries (Michaelis and Reise 1994). Blue mussel beds are one of the last habitat features left, but are also one of the last fisheries resources. A fishery for blue mussels first started in 1887 on natural beds and expanded to cultured beds in the 1950s (Fig. 4; Dahl et al. 1994; Lozan 1994). Since the 1970s, a decline of wild mussel beds in the sublittoral and eulittoral has been observed throughout the Wadden Sea (Fig. 7), which is probably the result of a long, intense and destructive fishery (Michaelis and Reise 1994; de Jong et al. 1999 and references therein). In particular, old, mature mussel beds with their associated communities are lost by intense fishing practices (Dahl et al. 1994). In some small areas with little fishing activity such as the Königshafen, Sylt, mussel beds have increased, possibly linked to enhanced food supply due to eutrophication (Reise et al. 1989).

Decline of large epifauna in the sublittoral

Repeated benthic surveys in subtidal channels in the north Frisian Wadden Sea demonstrated strong declines of large epifauna during 1924-1940 and 1985-1988

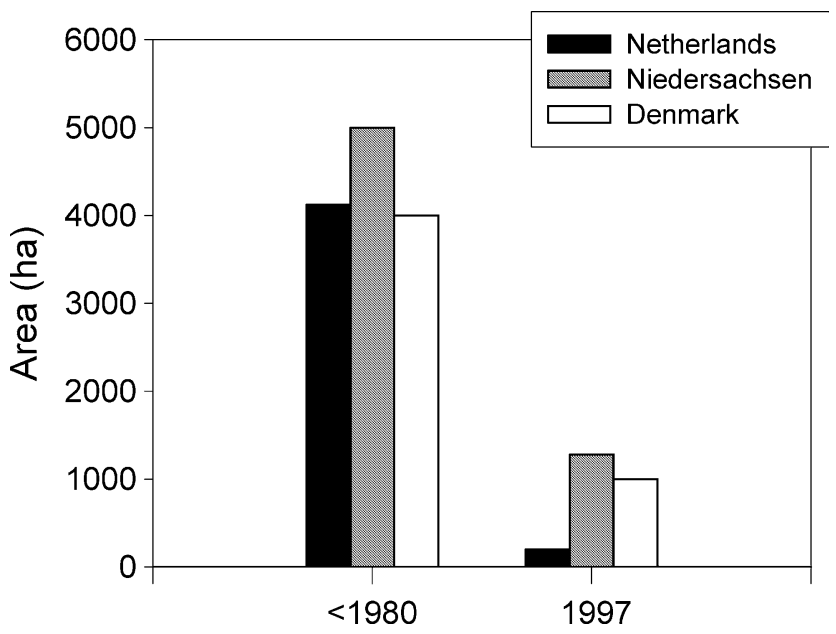

Fig. 7 Decline in the spatial extend of blue mussel beds in three regions of the Wadden Sea. Data adapted from de Jong et al. (1999) and references therein 
(Fig. 8a; Reise et al. 1989; Buhs and Reise 1997). Causes for the decline are habitat loss (e.g. oysters banks, $S a$ bellaria reefs), erosion and continued bottom fishery that destroys habitat and prevents its recovery (Dahl et al. 1994). Moreover, the bottom fishery takes a variety of benthic species as bycatch. For example, with the introduction and increasing effort of the beam trawl fishery in the southeastern North Sea since 1965, bycatch rates of several species of whelks, squids, lobsters, crabs, sea urchins and sea anemones first increased but then declined during the 1970-1980s despite continuously high fishing effort (Philippart 1998). Another threat to several gastropods comes from pollution. The antifouling agent tributyltin (TBT) causes imposex and is at least partly responsible for the decline of the common whelk (Nehring 2000).

Increase in infauna and exotic species in the eulittoral

Contrary to the decline of large epifauna, an increase could be observed in the infauna of mud and sand flats in the 1980s compared to the 1930s in the north Frisian Wadden Sea (Fig. 8b). Polychaetes increased especially in abundance, but overall species richness increased as well (Fig. 8b; Reise et al. 1989). Similar trends have been
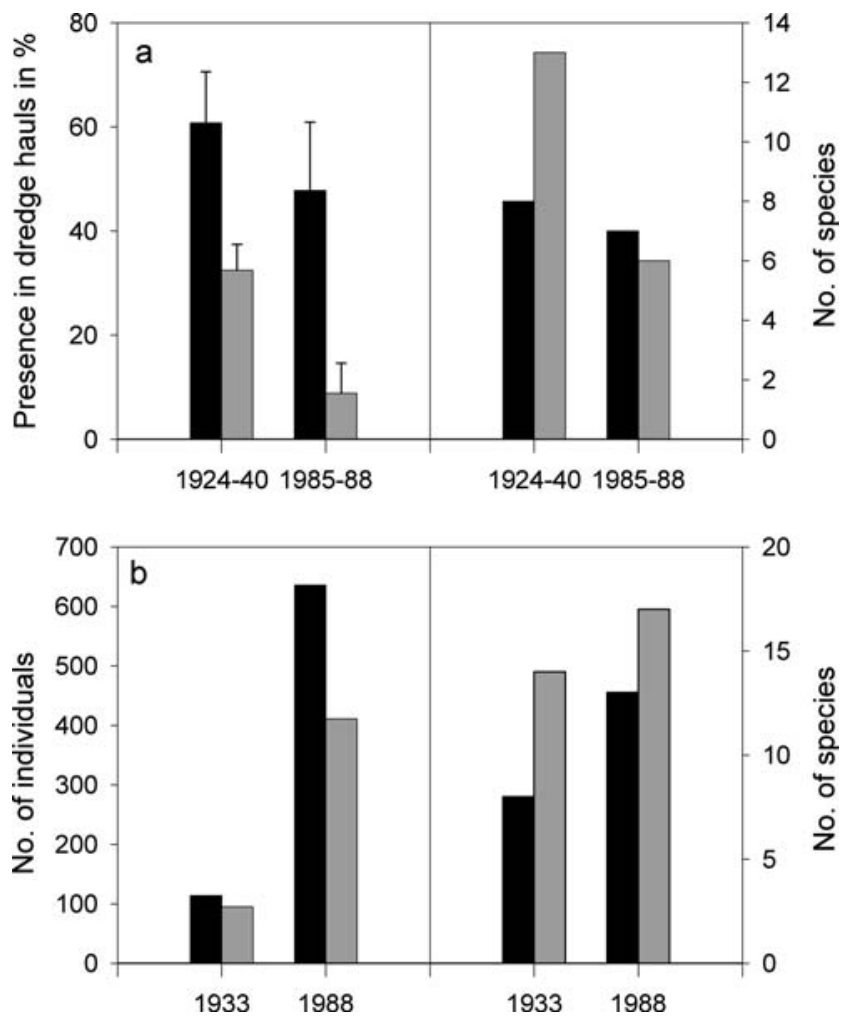

Fig. 8 Relative abundance (left axes) and species richness (right axes) of (a) large mobile (black bars) and sessile (gray bars) epifauna $(>60 \mathrm{~mm})$ in subtidal channels between 1924 and 1988 and (b) infauna $\left(>1 \mathrm{~mm}\right.$ ) in clean sand (black bars, per $1,500 \mathrm{~cm}^{2}$ ) and lugworm flats (gray bars, per 2,000 $\mathrm{cm}^{2}$ ) between 1933 and 1988. Data adapted from Reise et al. (1989) observed in the Dutch Wadden Sea since the 1970s, and may be explained by enhanced food supply due to eutrophication, by trawling that indirectly favours polychaetes which recover quickly, or by the decline in predators (Reise et al. 1989; Essink et al. 1998; Beukema et al. 2002). However, these trends are not uniform in the Wadden Sea and could not be confirmed in Denmark, Norderney (Germany) or Groningen (the Netherlands) (Essink et al. 1998). An overall increase in eulittoral species richness is a consequence of introduced species (Michaelis and Reise 1994). Several mussels, snails, polychaetes, crabs, barnacles and other invertebrates have been introduced over time, especially in the 20th century. Possibly, the two earliest exotics were the soft-shelled clam Mya arenaria and the polychaete Teredo navalis (Michaelis and Reise 1994; Reise et al. 1999). Some introduced species, such as the razor clam Ensis americanus (1978) and the polychaete Marenzelleria $\mathrm{cf}$. wireni (1983), spread over the Wadden Sea and became new food sources for seabirds and flatfish (de Jong et al. 1999). Although negative interactions may occur, no extinctions or dramatic declines of native species have so far been ascribed to invaders (Wolff 2000a).

\section{Marine plants}

Decline and extinction of eelgrass beds

Before the 1930s, vast areas of the Dutch, German and Danish sublittoral Wadden Sea were presumably covered by meadows of the common eelgrass (Zostera marina). In the Dutch Wadden Sea, data from 1869 to 1930 indicate that eelgrass beds once occurred over 65$150 \mathrm{~km}^{2}$ (de Jonge and de Jong 1992; van Katwijk 2003). In the period 1923-1931, sublittoral eelgrass beds were commercially harvested near Texel and Wieringen (the Netherlands), with an annual cut of 317-789 tons dry weight (de Jonge and de Jong 1992). In the 1930s, the wasting disease (Labyrinthula zosterae) caused dramatic declines in eelgrass beds throughout the North Atlantic. During this time, sublittoral eelgrass beds in the Wadden Sea disappeared and never reestablished (Reise et al. 1989; de Jonge and de Jong 1992). Eulittoral eelgrass beds consisting of both $Z$. marina and $Z$. noltii also strongly declined in the 1930 s but partly recovered afterwards, e.g. in the Königshafen, Sylt, in the 1970s to the 1980s (Reise et al. 1989). However, eulittoral eelgrass beds have decreased in the Dutch and east Frisian Wadden Sea since the 1960s and 1970s, respectively (de Jonge et al. 1996; Kastler and Michaelis 1997). Increased turbidity, eutrophication and macroalgal blooms, and the direct effects of the mussel fisheries are discussed as being the main factors contributing to recent eelgrass declines (de Jonge and de Jong 1992; de Jonge et al. 1996). Today, less than $1 \mathrm{~km}^{2}$ of eelgrass beds remain in the Dutch Wadden Sea, $8.2 \mathrm{~km}^{2}$ in the east Frisian, and $38 \mathrm{~km}^{2}$ in the north Frisian (de Jonge et al. 1996; Kastler and Michaelis 1997; Reise 2000). 
Increase in green algae

Green macroalgae were present but unimportant in the Wadden Sea until the second half of the 20th century, when abundance started to increase due to enhanced nutrient loading. An increase was first observed in the western Wadden Sea in the late 1950s, and in the entire Wadden Sea since the 1970s (van den Hoek et al. 1979; Reise et al. 1989, 1994; Kolbe et al. 1995). In the 1990s, mass blooms of Enteromorpha, Ulva, Chaetomorpha and Cladophora occurred on up to $15 \%$ of tidal flats between the Ems and Elbe rivers (Kolbe et al. 1995), and up to $40-60 \%$ on tidal flats near Juist and Borkum, Germany (Reise et al. 1994). Consequences of such algal mass developments are overgrowth, burial, and mass mortality of epi- and infauna due to anoxic conditions under decaying algal carpets (Schories 1995; de Jong et al. 1999).

Decline of red and brown seaweeds

Another pattern of change is the long-term decrease in the number of red and brown algal species recorded by researchers in the Königshafen, Sylt, during different periods of the 19th and 20th centuries, contrasting with the increase in green algal species (Fig. 9a; Schories et al. 1997). Relative abundance of red and brown algae in subtidal channels of the north Frisian Wadden Sea also decreased from the 1930-1940s to the period 1987-1988, while relative abundance of green algae increased (Fig. 9b; Reise et al. 1989). While the increase in green algae is caused by increased nutrient loading (Reise et al. 1989; Reise 2000), the decrease in red and brown algae may be attributed to increased water turbidity and the loss of habitat such as eelgrass beds and oyster reefs that provided solid surfaces for attachment (Reise et al. 1989; Wolff 2000a). In contrast, many green algae are able to use Hydrobia shells or sand grains for germination and live in a free-floating stage afterwards (Schories 1995).

\section{Conclusions}

This overview documents that the Wadden Sea flora and fauna has been changed by humans over past centuries and millennia. Of course, the Wadden Sea has experienced natural ecological changes throughout its history. However, at least since the Middle Ages, humans have been a major and increasing driver of change as well. Human impacts began with exploitation, progressed to habitat alteration, and further to habitat destruction, habitat extinction, eutrophication, pollution, species introductions and recently also climate change (see also Lotze et al. 2005). The general response of the Wadden Sea fauna and flora has been the loss and decline of large, long-lived, slow-growing and specialized species and an increase in small, short-living, fast-growing and opportunistic species. The dramatic loss of large pre-
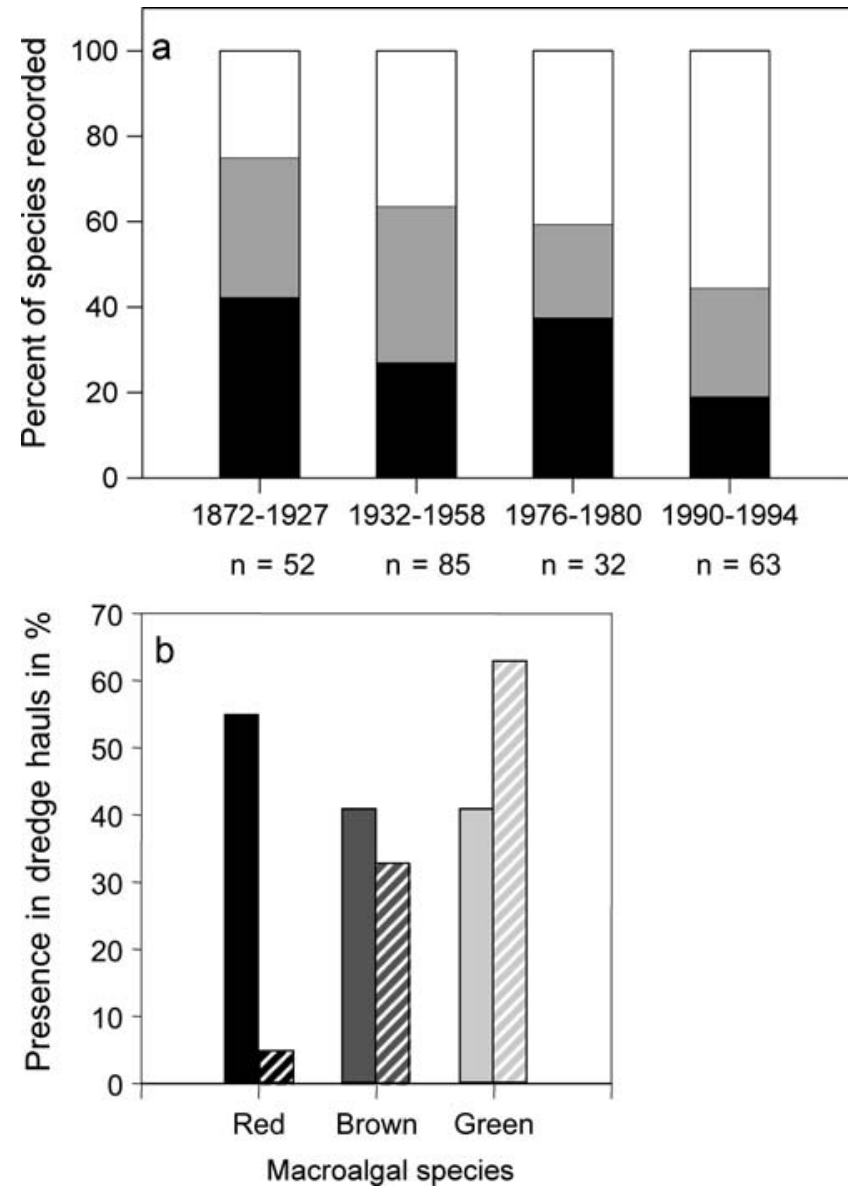

Fig. 9 (a) Percentage of red (black), brown (gray) and green (white) macroalgal species recorded in Königshafen, Sylt, in different periods during the 19th to the 20th century ( $n=$ total no. of species recorded, after Schories et al. 1997). (b) Relative abundance of red, brown and green algae dredged in tidal channels in the north Frisian Wadden Sea in 1932-1940 (filled bars, $n=27$ ) compared to 1987-1988 (hatched bars, $n=78$ ) after Reise et al. (1989)

dators such as whales, large groundfish, diadromous fish and many birds has severely simplified food-web structure (see also Lotze et al. 2005). The almost complete loss of habitat-building species such as oyster banks, Sabellaria reefs and eelgrass meadows has homogenized the Wadden Sea seascape, strongly reduced complex, three-dimensional habitats, and caused the disappearance of associated communities. The degradation of water quality through eutrophication and pollution harms species and impairs recovery. These ecological changes also affect coastal economies: of more than 20 commercial fisheries in the 19th century, only 3 or 4 still exist today (Lozan 1994; Holm 2005; Wolff 2005). Harmful algal blooms and beach closures affect water quality and hence tourism. Pollutants affect seafood quality and human health. On the other hand, reduced hunting pressure and increased habitat protection in the 20th century enabled several birds and seals to recover. They became attractions for tourists, bird watchers and coastal inhabitants. Although radically changed, the Wadden Sea ecosystem is still of great natural value. 
Many species still exist in the region, although at much reduced levels. Their recovery could be supported by restoring and protecting their habitat, reducing direct and indirect exploitation pressure, and reducing pollution. A rich, diverse, and healthy Wadden Sea ecosystem has great potential and value for both nature and society.

Acknowledgements I am grateful to all colleagues who provided data, literature and insights. Comments by Karsten Reise, Wim Wolff, Victor de Jonge and Boris Worm greatly improved the scope and clarity of the manuscript. This work was partly funded by the History of Marine Animal Populations project of the Census of Marine Life and the Stiftung Alfred-Wegener Institute for Polar and Marine Research

\section{References}

Behm-Berkelmann K, Heckenroth H (1991) Übersicht der Brutbestandsentwicklung ausgewählter Vogelarten 1900-1990 an der niedersächsischen Nordseeküste. Naturschutz- und Landschaftspflege in Niedersachsen 27:1-97

Benke H, Siebert U (1994) Zur Situation der Kleinwale im Wattenmeer und in der südlichen Nordsee. In: Lozan JL, Rachor E, Reise K, von Westernhagen H, Lenz W (eds) Warnsignale aus dem Wattenmeer. Blackwell, Berlin, pp 309-316

Beukema JJ, Cadée GC, Dekker R (2002) Zoobenthic biomass limited by phytoplankton abundance: evidence from parallel changes in two long-term data series in the Wadden Sea. J Sea Res 48:111-125

Buhs F, Reise K (1997) Epibenthic fauna dredged from tidal channels in the Wadden Sea of Schleswig-Holstein: spatial patterns and a long-term decline. Helgol Mar Res 51:343-359

Bryant PJ (1995) Dating remains of gray whales from the eastern North Atlantic. J Mammalogy 76:857-861

Christensen V, Guenette S, Heymans JJ, Wlaters CJ, Watson R, Zeller D, Pauly D (2003) Hundred-year decline of North Atlantic predatory fishes. Fish Fisheries 4:1-24

Dahl K, Borchardt T, Dankers N, Farke H (1994) Status, trends, regulation and ecological effects of the Wadden Sea fishery. Ophelia Suppl 6:87-97

Dankers N, Wolff WJ, Zijlstra JJ (1978) Fishes and fisheries of the Wadden Sea. Report 5 of the Wadden Sea Working Group, Stichting Veth tot Steun aan Waddenonderzoek, Leiden, The Netherlands

Dankers N, Kuehl H, Wolff WJ (1981) Invertebrates of the Wadden Sea. Report 4 of the Wadden Sea Working Group, Stichting Veth tot Steun aan Waddenonderzoek, Leiden, The Netherlands

De Jonge VN, de Jong DJ (1992) Role of tide, light and fisheries in the decline of Zostera marina L. in the Dutch Wadden Sea. Neth Inst Sea Res Publ Ser 20:161-176

De Jonge VN, Essink K, Boddeke R (1993) The Dutch Wadden Sea: a changed ecosystem. Hydrobiologia 265:45-71

De Jonge VN, de Jong DJ, van den Berg J (1996) Reintroduction of eelgrass (Zostera marina) in the Dutch Wadden Sea; review of research and suggestions for management measures. J Coast Conserv 2:149-158

De Jong F, Bakker J, Berkel Cv, Dahl K, Dankers N, Gätje C, Marencic H, Potel P (1999) Wadden Sea quality status report. Wadden Sea Ecosyst 9:1-259

De Smet WMA (1981) Evidence of whaling in the North Sea and English Channel during the Middle Ages. FAO Fish 3(5):301-309

De Vooys CGN, Witte JI, Dapper R, van der Meer JM, van der Veer HW (1991) Lange termijn veranderingen in zeldzame vissoorten op het nederlans continentaal plat van de noordzee. Nederlands Instituut voor Onderzoek der Zee. NIOZ-Rapport 1991-1996
Debus L (1996) The decline of the European sturgeon Acipenser sturio in the Baltic and North Sea. In: Kirchhofer A, Hefti D (eds) Conservation of endangered freshwater fish in Europe. Birkhäuser Verlag, Basel, Switzerland, pp 147-156

Drinkwaard AC (1999) Introductions and developments of oysters in the North Sea area: a review. Helgol Meeresunters 52:301308

Enghoff IB (2000) Fishing in the southern North Sea region from the 1st to the 16th century AD: evidence from fish bones. Archaeofauna 9:59-132

Essink K, Beukema JJ, Madsen PB, Michaelis H, Vedel GR (1998) Long-term development of biomass of intertidal macrozoobenthos in different parts of the Wadden Sea. Governed by nutrient loads? Proceedings of the 9th International Wadden Sea Symposium, November 1996, Norderney. Senckenbergiana marit 29:25-36

Flemming BW (2002) Effects of climate and human interventions on the evolution of the Wadden Sea depositional system (southern North Sea). In: Wefer G, Berger W, Behre K-E, Jansen E (eds) Climate development and the history of the North Atlantic Realm. Springer, Berlin Heidelberg New York, pp 399-413

Froese R, Pauly D (2003) Dynamik der Überfischung. In: Lozan JL, Rachor E, Reise K, Sündermann J, von Westernhagen $H$ (eds) Warnsignale aus Nordsee und Wattenmeer: eine aktuelle Umweltbilanz. Wissenschaftliche Auswertungen, Hamburg, pp 288-295

Ganter B (2000) Seagrass (Zostera spp.) as food for brent geese (Branta bernicla): an overview. Helgol Mar Res 54:63-70

Hagmeier A, Kändler R (1927) Neue Untersuchungen im nordfriesischen Wattenmeer und auf den fiskalischen Austernbänken. Wissenschaftl Meeresunters (Helgoland) 16:1-90

Heinrich D (1994) Die Fischreste aus der frühgeschichtlichen Wurt Elisenhof. Studien zur Küstenarchäologie Schleswig-Holsteins Serie A 6:215-271

Hoffmann RC (2005) A brief history of aquatic resource use in Medieval Europe. Helgol Mar Res (in press)

Holm P (2005) Human impacts on fisheries resources and abundance of the Danish Wadden Sea, $c 1520$ to the present. Helgol Mar Res (in press - this volume)

Jennings S, Blanchard JL (2004) Fish abundance with no fishing: predictions based on macroecological theory. J Anim Ecol 73:632-642

Johnson KR, Nelson CH (1984) Side-scan sonar assessment of Gray whale feeding in the Bering Sea. Science 225:1150-1152

Kastler T, Michaelis H (1997) Der Rückgang der Seegrasbestände im Niedersächsischen Wattenmeer. Ber Forsch.-Stelle Küste Norderney 41:119-139

Knottnerus (2001) The Wadden Sea region: a unique cultural landscape. In: Vollmer M, Guldberg M, Maluck M, Marrewijk D, Schlicksbier G (eds) Landscape and cultural heritage in the Wadden Sea Region-project report. Wadden Sea Ecosystem 12:12-71

Kolbe K, Kaminski E, Michaelis H, Obert B, Rahmel J (1995) Macroalgal mass development in the Wadden Sea: first experiences with monitoring system. Helgol Meeresunters 49:519528

Kremer H (1990) Zur Situation der Wale in der Nordsee-unter Berücksichtigung des Schweinswales (Phocoena phocoena L.). In: Lozan JL, Lenz W, Rachor E, Watermann B, Westernhagen Hv (eds) Warnsignale aus der Nordsee. Parey, Berlin, pp 331342

Løppenthin B (1967) Danske ynglefugle i fortid og nutid. Universitetsforlag, Odense, Denmark

Lotze HK, Reise K, Worm B, Beusekom JEE van, Busch M, Ehlers A, Heinrich D, Hoffmann RC, Holm P, Jensen C, Knottnerus OS, Langhanki N, Prummel W, Vollmer M, Wolff WJ (2005) Human transformations of the Wadden Sea ecosystem through time: a synthesis. Helgol Mar Res (in press - this volume)

Lozan JL (1990) Fische. In: Lozan JL, Lenz W, Rachor E, Watermann B, von Westernhagen $\mathrm{H}$ (eds) Warnsignale aus der Nordsee. Parey, Berlin, pp 230-249 
Lozan JL (1994) Zur Geschichte der Fischerei im Wattenmeer und in Küstennähe. In: Lozan JL, Rachor E, Reise K, von Westernhagen $\mathrm{H}$, Lenz W (eds) Warnsignale aus dem Wattenmeer. Blackwell, Berlin, pp 215-226

Lozan JL, Zimmermann C (2003) Zustand der Nutzfischbestände der Nordsee-insbesondere der dermersalen Fischarten. In: Lozan JL, Rachor E, Reise K, Sündermann J, von Westernhagen $\mathrm{H}$ (eds) Warnsignale aus Nordsee und Wattenmeer: eine aktuelle Umweltbilanz. Wissenschaftliche Auswertungen, Hamburg, pp 266-271

Lozan JL, Breckling P, Fonds M, Krog C, van de Veer HW, Witte JI (1994) Über die Bedeutung des Wattenmeeres für die Fischfauna und deren regionale Veränderung. In: Lozan JL, Rachor E, Reise $\mathrm{K}$, von Westernhagen $\mathrm{H}$, Lenz W (eds) Warnsignale aus dem Wattenmeer. Blackwell, Berlin, pp 226234

Magnus O (1555) Description of the northern peoples. Hakluyt Society London 1998, Rome 1555

Meltofte H, Blew J, Frikke J, Rösner H-U, Smit CJ (1994) Numbers and distribution of waterbirds in the Wadden Sea. Results and evaluation of 36 simultaneous counts in the Dutch-German-Danish Wadden Sea 1980-1991. IWRB Publication 34/ Water Study Group Bulletin 74, Special issue:1-192

Michaelis H, Reise K (1994) Langfristige Veränderungen des Zoobenthos im Wattenmeer. In: Lozan JL, Rachor E, Reise K, von Westernhagen $\mathrm{H}$, Lenz W (eds) Warnsignale aus dem Wattenmeer. Blackwell, Berlin, pp 106-116

Mohr E (1952) Der Stör. Akademische Verlagsgesellschaft, Geest \& Portig, Leipzig

Nehring S (2000) Long-term changes in Prosobranchia (Gastropoda) abundances on the German North Sea coast: the role of the anti-fouling biocide tributyltin. J Sea Res 43:151-165

Neudecker T (1990) The history of the former German oyster fishery and mariculture: 400 years of crown law on oyster (4.2.1587). Dt Hydrogr Z Erg-H B 22:518-525

Perry SL, DeMaster DP, Silber GK (1999) The Great Whales: history and status of six species listed as endangered under the U.S. Endangered Species Act of 1973. Mar Fish Rev Spec Iss 61:1-74

Philippart CJM (1998) Long-term impact of bottom fisheries on several by-catch species of demersal fish and benthic invertebrates in the south-eastern North Sea. ICES J Mar Sci 55:342-352

Plinii Secundi C (1513) Naturalis historiae. Libri XXXVII, Liber $\mathrm{X}$, Venice

Prummel W, Heinrich D (2005) Archaeological evidence of former occurrence and changes in fishes, amphibians, birds, mammals and molluscs in the Wadden Sea area. Helgol Mar Res (in press - this volume)

Reichstein H (1994) Die Säugetiere und Vögel aus der frühgeschichtlichen Wurt Elisenhof. Studien zur Küstenarchäologie Schleswig-Holsteins Serie A 6:1-214

Reijnders PJH (1992) Retrospective population analysis and related future management perspectives for the harbour seal Phoca vitulina in the Wadden Sea. Neth Inst Sea Res Publ Ser 20:193-197

Reijnders PJH, Wolff WJ (1981) Marine mammals of the Wadden Sea. Report 7 of the Wadden Sea Working Group, Stichting Veth tot Steun aan Waddenonderzoek, Leiden, The Netherlands

Reineking B (2002) Phocine Distemper epidemic amongst seals in 2002. Wadden Sea Newsl 2:3-8

Reise K (1990) Karl Möbius: Dredging the first community concept from the bottom of the sea. Dt Hydrogr Z Erg-H B 22:149-152

Reise K (1998) Einstige Austernbänke. In: Landesamt für den Nationalpark Schleswig-Holsteinisches Wattenmeer, Umweltbundesamt (ed) Umweltatlas Wattenmeer Bd. 1 Nordfriesisches und Dithmarscher Wattenmeer. Ulmer, Stuttgart, pp $168-169$

Reise K (2000) Seegraswiesen und Grünalgenmatten im SchleswigHolsteinischen Wattenmeer: Verteilung und langfristige Bestandsänderungen. Wattenmeermonitoring 1998-Schriftenreihe des Nationalparks Schleswig-Holsteinisches Wattenmeer, Tönning, pp 5-7
Reise K (2005) Coast of change: Habitat loss and transformations in the Wadden Sea. Helgol Mar Res (in press - this volume)

Reise K, Herre E, Sturm M (1989) Historical changes in the benthos of the Wadden Sea around the island of Sylt in the North Sea. Helgol Meeresunters 43:417-433

Reise K, Kolbe K, de Jonge VN (1994) Makroalgen und Seegrasbestände im Wattenmeer. In: Lozan JL, Rachor E, Reise K, von Westernhagen $\mathrm{H}$, Lenz $\mathrm{W}$ (eds) Warnsignale aus dem Wattenmeer. Blackwell, Berlin, pp 90-100

Reise K, Gollasch S, Wolff WJ (1999) Introduced marine species of the North Sea coasts. Helgol Meeresunters 52:219-234

Rösner H-U (1994) Population indices for migratory birds in the Schleswig-Holstein Wadden Sea from 1987-1993. Ophelia Suppl 6:171-186

Schories D (1995) Populationsökologie und Massenentwicklung von Enteromorpha spp. (Chlorophyta) im Sylter Wattenmeer. Disserationt, University of Hamburg, Hamburg

Schories D, Albrecht A, Lotze HK (1997) Historical changes and inventory of macroalgae from Königshafen Bay in the northern Wadden Sea. Helgol Meeresunters 51:321-341

Schwarz J, Heidemann G (1994) Zum Status der Bestände der Seehund- und Kegelrobbenpopulationen im Wattenmeer. In: Lozan JL, Rachor E, Reise K, von Westernhagen H, Lenz W (eds) Warnsignale aus dem Wattenmeer. Blackwell, Berlin, pp 296-303

Swennen C (1991) Ecology and populatino dynamics of the common eider in the Dutch Wadden Sea. PhD thesis, $\mathrm{Ri}_{-}$ jksuniversiteit Groningen

Tiews K (1983) Über die Veränderungen im Auftreten von Fischen und Krebsen im Beifang der deutschen Garnelenfischerei während der Jahre 1954-1981. Arch Fisch Wiss 324:1-156

Tiews K (1990) Langzeitentwicklung von 25 Fisch- und Krebstierbeständen im deutschen Wattenmeer (1954-1988). In: Lozan JL, Lenz W, Rachor E, Watermann B, von Westernhagen $\mathrm{H}$ (eds) Warnsignale aus der Nordsee. Parey, Berlin, pp $250-251$

TSEG (Trilateral Seal Expert Group-plus) (2002) Common and grey seals in the Wadden Sea. Wadden Sea Ecosyst 15:1-96

van den Hoek C, Admiraal W, Colijn F, de Jonge VN (1979) The role of algae and seagrasses in the ecosystem of the Wadden Sea. In: Wolff WJ (ed) Flora and vegetation of the Wadden Sea. Report 3 of the Wadden Sea working group. Stichting Veth tot Steun aan Waddenonderzoek, Leiden, Netherlands, pp 9-118

van Eerden MR (1997) Long-term changes in wetland area and composition in the Netherlands affecting the carrying capacity for wintering water birds. In: van Eerden MR (ed) Patchwork, patch use, habitat exploitation and carrying capacity for water birds in Dutch freshwater wetlands. Ph.D. thesis, Rijksuniversiteit Groningen, Groningen, the Netherlands, pp 3156

van Katwijk MM (2003) Reintroduction of eelgrass (Zostera marina L.) in the Dutch Wadden Sea: a research overview and management vision. In: Wolff WJ, Essink K, Kellermann A, van Leeuwe MA (eds) Challenges to the Wadden Sea Area. In: Proceedings of the 10th International Scientific Wadden Sea Symposium, Groningen, The Netherlands, pp 173-195

von Nordheim H, Andersen ON, Thissen J (1996) Red lists of biotopes, flora and fauna of the Trilateral Wadden Sea Area, 1995. Helgol Meeresunters 50(Suppl):1-136

Walhorn A, Heinrich D (1999) Untersuchungen an Tierknochen aus der mittlealterlichen Wurt Niens, Ldkr. Wesermarsch. Probleme der Küstenforschung im südlichen Nordseegebiet 26:209-262

Wolff WJ (ed) (1983) Ecology of the Wadden Sea. Balkema, Rotterdam

Wolff WJ (1992a) Ecological developments in the Wadden Sea until 1990. Neth Inst Sea Res Publ Ser 20:23-32

Wolff WJ (1992b) The end of a tradition: 1000 years of embankment and reclamation of wetlands in the Netherlands. Ambio 21:287-291

Wolff WJ (2000a) Causes of extirpations in the Wadden Sea, an estuarine area in the Netherlands. Conserv Biol 14:876-885 
Wolff WJ (2000b) The south-east North Sea: losses of vertebrate fauna during the past 2000 years. Biol Conserv 95:209-217

Wolff WJ (2005) The exploitation of living resources of the Dutch Wadden Sea: an historical overview. Helgol Mar Res (in press this volume)
Zimmermann C, Hammer C (2003) Zustand der pelagischen Nutzfischbestände in der Nordsee. In: Lozan JL, Rachor E, Reise K, Sündermann J, von Westernhagen $\mathrm{H}$ (eds) Warnsignale aus Nordsee und Wattenmeer: eine aktuelle Umweltbilanz. Wissenschaftliche Auswertungen, Hamburg, pp 272-276 